Annals of Warsaw University of Life Sciences - SGGW

Land Reclamation No 43 (1), 2011: 25-35

(Ann. Warsaw Univ. of Life Sci. - SGGW, Land Reclam. 43 (1), 2011)

\title{
Application of the WetSpa distributed hydrological model for catchment with significant contribution of organic soil. Upper Biebrza case study
}

\author{
CHORMAŃSKI JAROSŁAW ${ }^{1}$, OKKE BATELAAN ${ }^{2,3}$ \\ ${ }^{1}$ Department of Hydraulic Structures, Warsaw University of Life Sciences - SGGW \\ ${ }^{2}$ Dept. of Hydrology and Hydraulic Engineering, Vrije Universiteit Brussel \\ ${ }^{3}$ Dept. of Earth and Environmental Sciences, K.U. Leuven
}

\begin{abstract}
Application of the WetSpa distributed hydrological model for catchment with significant contribution of organic soil. Upper Biebrza case study. The paper treats on hydrological distributed model adaptation for a catchment with significant contribution of wetland. The WetSpa model was applied to analyzing the effects of topography, soil type, and land use cover on the runoff characteristics for upper Biebrza catchment. The derivation of parameter maps and analysis of the daily runoff as reaction of the catchment on rainfall was performed. The semi-automated calibration of the model was executed using PEST module. Then, the assessment of that crucial processes was done by calculating errors of mathematical models performance as well as hydrograph comparison. Error values, have shown that the model efficiency was estimated to be good for high flows, but unsatisfactory for low flows. This initial modeling approach gives possibility to ask question about limitation and needs of wetland catchment for rainfall-runoff modeling.
\end{abstract}

Key words: distributed modeling, rainfall-runoff process, automatic calibration, lowland catchment.

\section{INTRODUCTION}

A prerequisite to integrated water management in area of Natura 2000 - a natural wide river valleys with riparian wetlands is to built up a proper understanding of the hydrological system. The quantity and quality of water in the natural valley is in high relation to hydrologi- cal situation in the whole catchment. The aim of this study is therefore to identify and quantify the key processes steering the hydrological functioning of the catchment with significant contribution of organic soil. The valley of the Biebrza River, is considered as an unique place on the european scale due to exceptional natural values of wetlands and peatlands. (Okruszko 1990).

Preserving the desired envinronmental status of the Biebrza wetlands is important for the quality and the quantity of water resources of Biebrza. The dominated hydrological processes in the Upper Biebrza are groundwater recharge and discharge, river discharge and to a lesser extent flooding conditions. Hydrological processes of the Upper Biebrza River catchment have currently been the subject of a wide research which includes GIS analysis (Wasilewski and Chormański 2009), groundwater study (Batelaan and Kuntohadi 2002; Van Loon et al. 2009), rainfall-runoff modeling in Biebrza tributaries (Porretta-Brandyk et al. 2010; 2011). In this paper, the research was focused on rainfall-runoff modeling for upper Biebrza catchment. The outflow hydrograph was simulated using WetSpa computer software (Wang 
et al. 1996; de Smedt et al. 2000, Liu et al. 2002). WetSpa is GIS based distributed hydrological model, partly phisically based. Distributed hydrological models are often linked to GIS and use capablities to estimate spatial parameters from topography and digital maps of soil type and land-use. The powerful GIS tools give new possibilities for hydrological research in understanding the fundamental physical processes underlying the hydrological cycle and the solution of mathematical equations representing those processes.

\section{STUDY AREA}

The upper Biebrza River catchment was chosen as research area. It is located in Northeast Poland. It includes the Upper Biebrza Basin - a protected river valley which is a part of the Biebrza National Park - added to the RAMSAR Convention list as one of the most important worldwide wetlands. The valley has been formed as an ice marginal valley and is relatively long $(40 \mathrm{~km})$ and narrow (2-3 km), which is crossed by numerous ditches of reclamation system build in 70 'ties of 20th century and play a role of floodplain during a spring floods. It is filled with the thick deposits of peat (usually $2-5 \mathrm{~m}$ ) partly underlain by gyttja layer $(1-4 \mathrm{~m})$. The area of the upper Biebrza River catchment is about $800 \mathrm{sq} \mathrm{km}$ (Fig. 1). It is a lowland catchment - is rather flat with mean slope of $1.2 \%$. Most of the slopes are smaller than $2.5 \%$. The arable land which consist of $44 \%$ of area is the main land use of the catchment located in the central and southern part of area. Agricultural developments pose a threat for the Biebrza wetlands, since increased nutrient input endangers the peat forming mesothropic ecosystems. Other important land use categories are grasslands covered organic lands in the valley used by extensive farming (17\%). The northern part of the catchment is covered by forest $(15 \%)$, which partly is formed as alder birch forest covered peatland. The total area of peatland in the catchment is more than $25 \%$.

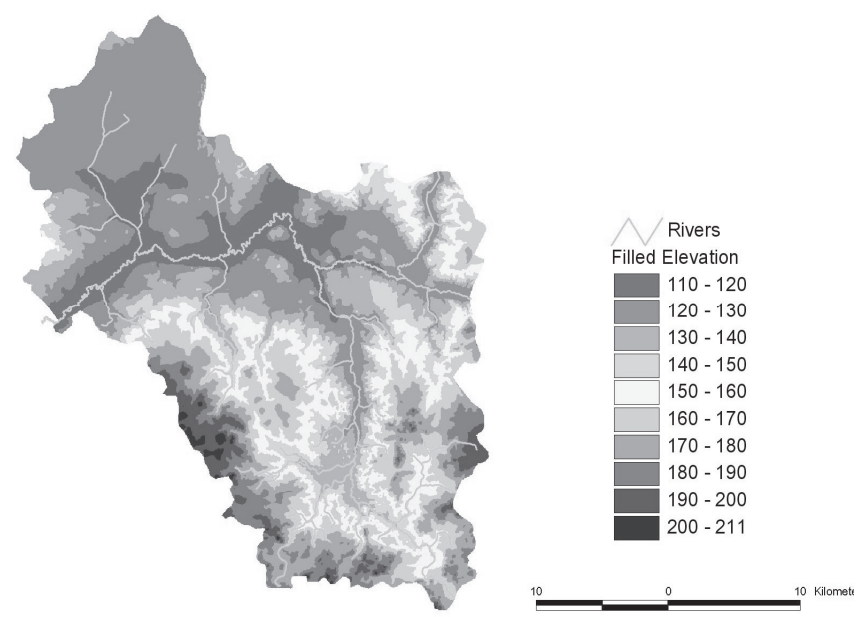

FIGURE 1. Digital Elevation Model of upper Biebrza River catchment 
The Biebrza River catchment is located in the subcontinantal/subboreal climate zone and has a yearly average temperature of $6.8^{\circ} \mathrm{C}$. An average annual precipitation ranges from 550 to $700 \mathrm{mmy}^{-1}$. A maximum precipitation has been noted in summer months (July and August) and in the Biebrza valley is equal to $65-70 \%$ of the yearly total (this is only $60 \%$ in the surrounding moraine plateaus (Kossowska-Cezak 1984).

The evapotranspiration is described being between 460 and $480 \mathrm{mmy}^{-1}$ (Kossowska-Cezak 1984). The growing season in the area is with 200 days relatively short. In spring and early summer snowmelt occurs, playing an important role in generating spring floods. Snow processes in the Upper Biebrza Basin represent a significant component of the hydrologic cycle and need to be considered in simulation of the hydrologic processes.

\section{MATERIALS AND METHODS}

A model selected for this work was the GIS-based distributed watershed model - WetSpa (developed for simulation of rainfall-runoff processes in the catchment scale). WetSpa is a grid-based hydrological model for water and energy transfer between soil, plants and atmosphere, which was originally developed by Wang et al. (1996) and adopted for flood prediction by de Smedt et al. (2000), Liu et al. (2002).

The model was successfully tested for flood hydrograph calculation in urbanized catchments (Chormański et al. 2008). In an actual version a model was developed as an ArcGIS 10 module
(Chormański and Michalowski 2011 - in press). For each grid cell a vegetation, root, transmission and saturated zone is considered in the vertical direction.

The hydrological processes parameterized in the model are: precipitation, interception, depression storage, surface runoff, infiltration, evapotranspiration, percolation, interflow and groundwater flow. The total water balance for a raster cell is composed of the water balance for the vegetated, bare soil, water and impervious parts of each cell. That makes possible to represent within-cell heterogeneity of the land cover. A mixture of physical and empirical relationships is used to describe the hydrological processes in the model. Interception reduces the precipitation to net precipitation, which on the ground is separated into rainfall excess and infiltration. Rainfall excess is calculated using a moisturerelated modified rational method with a potential runoff coefficient depending on land cover, soil type, slope, rainfall intensity, and antecedent moisture content of the soil. The calculated rainfall excess fills the depression storage at the initial stage and runs off the land surface simultaneously as overland flow.

Runoff from different cells in the watershed is routed to the watershed outlet depending on flow velocity and wave damping coefficient by using the diffusive wave approximation method. An approximate solution proposed by $\mathrm{De}$ Smedt et al. (2000) in the form of an instantaneous unit hydrograph (IUH) was used in the model, relating the discharge at the end of a flow path to the available runoff at the start of the flow path (De Smedt et al. 2000): 


$$
\begin{aligned}
& u(t)=\frac{1}{\sigma \sqrt{2 \pi t^{3} / t_{0}^{3}}} \exp \left[\frac{\left(t_{o}-t\right)^{2}}{4 \sigma^{2} t / t_{o}}\right] \\
& Q(t)=\iint_{A}^{t} Q_{o}(\tau) U(t-\tau) d \tau d A
\end{aligned}
$$

where:

$u(t) \mathrm{i}$ - the unit response function $\left(\mathrm{s}^{-1}\right)$, $Q(t)$ - the outlet flow hydrograph $\left(\mathrm{m}^{3} / \mathrm{s}\right)$, $Q_{0}$ - the inflow at the start of the flow path $\left(\mathrm{m}^{3} / \mathrm{s}\right)$,

$t_{0}$ - the average travel time (s) to the outlet along the flow path and $\sigma$ is the standard deviation (s) of the flow time,

$Q_{o}$ - the excess precipitation in a grid cell, $\mathrm{L} \cdot \mathrm{T}^{-1}$;

$\tau$ - the time delay, $\mathrm{T}$,

$A$-drainage area of the watershed, $\mathrm{L}^{2}$.

Parameters $t_{0}$ and $\sigma$ are spatially distributed, and can be obtained by integration along the topographically determined flow paths as a function of flow celerity and dispersion. Although the spatial variability of land use, soil and topographic properties within a watershed are considered in the model, the groundwater response is modelled on sub-catchment scale. The simple concept of a linear reservoir is used to estimate groundwater discharge, while a non-linear reservoir method is optional in the model (Wittenberg, Sivapalan 1999). The groundwater outflow is added to the generated runoff to produce the total stream flow at the sub-watershed outlet. Time-dependent inputs of the model are precipitation and potential evapotranspiration.

Model parameters such as interception and depression storage capacity, potential runoff coefficient, overland roughness coefficient, root depth, soil property parameters, average travel time to the outlet, dispersion coefficient, etc., are determined for each grid cell using lookup tables and a high-resolution DEM, soil type and land-use maps (Fig. 2). The main outputs of the model are river flow hydrographs, which can be defined for any location along the channel network, and spatially distributed hydrological characteristics, such as soil moisture, infiltration rates, groundwater recharge, surface water retention, runoff, etc. (Liu 2004).

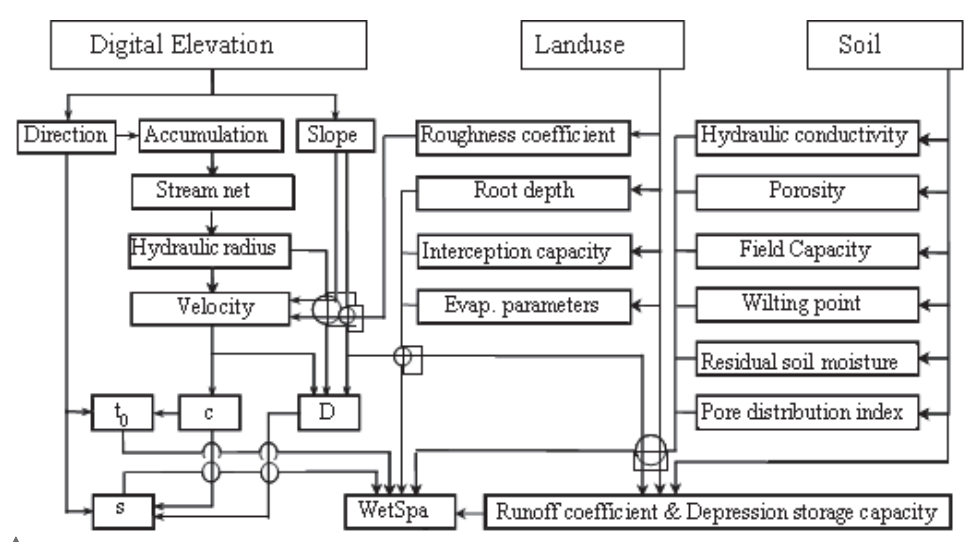

FIGURE 2. Parameterization of local parameters in WetSpa model (Liu 2004) 


\section{MODEL CALIBRATION AND EVALUATION}

The rough calibration is performed automatically with PEST, a model-independent non-linear parameter estimator, which is implemented in WetSpa. Then, a finetuning calibration is performed manually. The calibration processes consist of running the model as many times as it needs to adjust model parameters within their predetermined range until the discrepancies between model outputs and a complementary set of flow observations is reduced. The model is evaluated by graphical comparison of simulated and observed hydrographs and assessment of goodness of fit between them by five statistical evaluation criteria CR1, CR2, CR3, CR4, and CR5 (Liu et al. 2003).

\section{CR1 - Model bias}

Model bias can be expressed as the relative mean difference between predicted and observed stream flows for a sufficiently large simulation sample, reflecting the ability of reproducing water balance, and perhaps the most important criterion for comparing whether a model is working well in practice. Error CR1 is the model bias, $\mathrm{Q}_{\mathrm{si}}$ and $\mathrm{Q}_{\mathrm{oi}}$ are the simulated and observed stream flows at time step $i\left(\mathrm{~m}^{3} / \mathrm{s}\right)$, and $\mathrm{N}$ is the number of time steps over the simulation period. Model bias measures the systematic under or over prediction for a set of predictions. A lower CR1 value indicates a better fit, and the value 0.0 represents the perfect simulation of observed flow volume. The criterion is given by the equation:

$$
C R 1=\frac{\sum_{i=1}^{N}\left(Q s_{i}-Q o_{i}\right)}{\sum_{i=1}^{N} Q o_{i}}
$$

\section{CR2 - Model confidence}

Model confidence is important criteria in assessment of continuous model simulation, and can be expressed by determination coefficient. CR2 represents the proportion of the variance in the observed discharges that are explained by the simulated discharges. It varies between 0 and 1 , with a value close to 1 indicating a high level of model confidence. It is given by the equation:

$$
C R 2=\frac{\sum_{i=1}^{N}\left(Q s_{i}-\bar{Q}_{o}\right)}{\sum_{i=1}^{N}\left(Q o_{i}-\bar{Q} o\right)^{2}}
$$

\section{CR3 - Nash-Sutcliffe efficiency}

The Nash-Sutcliffe coefficient (Nash and Sutcliffe 1970) describes how well the stream flows are simulated by the model. This efficiency criterion is commonly used for model evaluation, because it involves standardization of the residual variance, and its expected value does not change with the length of the record or the scale of runoff. The Nash-Sutcliffe efficiency is used for evaluating the ability of reproducing the time evolution of stream flows. The CR3 value can range from a negative value to 1 , with 1 indicating a perfect fit between the simulated 
and observed hydrographs. CR3 below zero indicates that average measured stream flow would have been as good a predictor as the modelled stream flow. A perfect model prediction has CR3 score equal to 1 . It has the form of:

$$
C R 3=\frac{\sum_{i=1}^{N}\left(Q o_{i}-\bar{Q} o\right)^{2}-\sum_{i=1}^{N}\left(Q o_{i}-Q s_{i}\right)^{2}}{\sum_{i=1}^{N}\left(Q o_{i}-\bar{Q} o\right)^{2}}
$$

\section{CR4 - Logarithmic version of Nash- -Sutcliffe efficiency for low flow evaluation}

CR4 is a logarithmic Nash-Sutcliffe efficiency for evaluating the ability of reproducing the time evolution of low flows, and e is an arbitrary chosen small value introduced to avoid problems with nil observed or simulated discharges. A perfect value of CR4 is.

$$
C R 4=1-\frac{\sum_{i=1}^{N}\left[\ln \left(Q s_{i}+\varepsilon\right)-\ln \left(Q o_{i}+\varepsilon\right)\right]^{2}}{\sum_{i=1}^{N}\left[\ln \left(Q o_{i}+\varepsilon\right)-\ln (Q o+\varepsilon)\right]^{2}}
$$

\section{CR5 - Adapted version of Nash- -Sutcliffe efficiency for high flow evaluation}

CR5 is an adapted version of Nash-Sutcliffe criterion for evaluating the ability of reproducing the time evolution of high flows. A perfect value of CR5 is 1 . To evaluate the goodness of the model performance during calibration and validation periods, the intervals listed in Table 2 have been adopted (Andersen et al. 2001). These criteria are not of the fail/ pass type, but evaluate the performance in the categories from excellent to very poor.

$$
C R 5=1-\frac{\sum_{i=1}^{N}\left(Q o_{i}+\bar{Q} o\right)\left(Q s_{i}-Q o_{i}\right)^{2}}{\sum_{i=1}^{N}\left(Q o_{i}+\bar{Q} o\right)\left(Q o_{i}-\bar{Q} o\right)^{2}}
$$

\section{Data}

Set of data required for a development of the hydrological model of the study area (Upper Biebrza catchment) incorporated non-spatial hydro-meteorological data and GIS data.

\section{Hydro-Meteorological data}

It needs to be pointed out that the data from only one measuring station were available. Discharge data was recorded in gauge station Sztabin - the outlet of the Upper Biebrza basin; temperature and precipitation at meteorological station in Rożanystok. Potential evapotranspiration was calculated using method proposed by Roguski et al. (1988) based on meteorological data from the Biebrza Meteorological Station, located outside of the catchment, in the distance of 20 $\mathrm{km}$ from discharge cross-sections. Meteorological service on both stations in Rożanystok and in Biebrza is provided by Institute of Meteorology and Water Management (IMGW). 
The daily data were used for modeling, and they has been divided in two parts. First part covers the period from 01.05.1988 - 31.12.2000 which was selected as the most recent period of which data were available. Second covers period of 01.11.1978 to 31.04.1981 - selected as a most wet period in last 60 years.

\section{GIS data}

GIS data layers - landuse, elevation and soil map in grid form have pixel size of 50 $\mathrm{m}$. A DEM of $30 \mathrm{~m}$ grid resolution was constructed from elevation contours, elevation measured points and existing river network. The elevation contours were obtained from topographic maps with a scale 1:25 000. The DEM was generated by TOPO to Raster function of ArcGIS.
The main source for interpolation were elevation contours in - additionally, for improving of elevation in the river valley where there are not many contours - elevation points were measured by GPS RTK technique. The CORINE LAND COVER 2000 was used as a Landuse map. The records were converting to WetSpa standard landuse types. Soil map was created based on digitizing of soil map in scale of 1:25 000 and converted to 12 USDA soil texture classes based on textural properties. The additionally organic soil was added to the standard list of soils used in WetSpa. The parameters for peat-mursh layer in the valley was obtained from Jan Szatyłowicz (not published expertise). Final values of soil textural characteristics which are used in model are presented in Table 1.

TABLE 1. Physical soil textural parameters used by WetSpa model

\begin{tabular}{|c|l|c|c|c|c|c|c|}
\hline $\begin{array}{l}\text { Soil- } \\
\text { type }\end{array}$ & \multicolumn{1}{|c|}{ Soil } & $\begin{array}{c}\text { Hydraulic } \\
\text { conductivity }\end{array}$ & Porosity & $\begin{array}{c}\text { Field } \\
\text { capacity }\end{array}$ & $\begin{array}{c}\text { Pore size } \\
\text { distribution } \\
\text { index }\end{array}$ & $\begin{array}{c}\text { Residual } \\
\text { moisture }\end{array}$ & $\begin{array}{c}\text { Wilting } \\
\text { point }\end{array}$ \\
\hline 1 & sand & 20880 & 437 & 62 & 34 & 20 & 24 \\
\hline 2 & loamy sand & 6120 & 437 & 105 & 39 & 35 & 47 \\
\hline 3 & sandy loam & 2592 & 453 & 190 & 45 & 41 & 85 \\
\hline 4 & silt loam & 1332 & 501 & 284 & 50 & 15 & 135 \\
\hline 5 & silt & 684 & 482 & 258 & 37 & 15 & 126 \\
\hline 6 & loam & 558 & 463 & 232 & 58 & 27 & 116 \\
\hline 7 & $\begin{array}{l}\text { sandy clay } \\
\text { loam }\end{array}$ & 432 & 398 & 244 & 72 & 68 & 136 \\
\hline 8 & silt clay loam & 230 & 471 & 342 & 83 & 40 & 210 \\
\hline 9 & clay loam & 151 & 464 & 310 & 83 & 75 & 187 \\
\hline 10 & sandy clay & 119 & 430 & 321 & 96 & 109 & 221 \\
\hline 11 & silt clay & 90 & 479 & 371 & 104 & 56 & 251 \\
\hline 12 & clay & 60 & 475 & 378 & 121 & 90 & 251 \\
\hline 13 & $\begin{array}{l}\text { peat and } \\
\text { organic }\end{array}$ & 2000 & 850 & 700 & 20 & 200 & 400 \\
\hline
\end{tabular}




\section{RESULTS AND DISCUSSION}

The overall objectives of model calibration are to find: a good agreement between the simulated and observed catchment runoff, a good overall agreement of the shape of the hydrograph, a good agreement of peak flows with respect to timing, rate and volume, and a good agreement of low flows. The focus is on spring and summer flood prediction, because these kind of floods ensure appropriate water conditions for preserving the wetlands.

In addition to the above objectives, the measured and simulated water balance components are reviewed. In order to evaluate the model, the simulation results are compared to the observed hydrograph both graphically and statistically.

Figure 3 shows the graphical comparison of simulated and observed flows for a wet period while Figure 4 - for a dry period. One can notice a reasonable agreement between the model results and the observed data for the wet period, ex- cept for the period from August ' 79 until March '80. Peaks in the hydrographs are rather well simulated, as well for flow volume and timing of occurrence. The model is able to predict all spring floods, but not to reproduce the flow volume for the extreme snowmelt flood event in April '79 producing a maximum discharge of $99 \mathrm{mz} / \mathrm{s}$. The reproduction of low flows on the other hand is not accurate (Fig. 4). Storm events during this period don't produce relevant floods compared with its measured storm volume as a large quantity of rainfall is used to saturate the wetlands, resulting in the gradual increase of measured base flow. The main reason for bad agreement for low flows in the upper Biebrza catchment is probably the simplification of the groundwater component in the model. Other reasons might be the less accurate estimation of the interception and evapotranspiration from groundwater storage during dry periods. In general, there is almost no surface runoff and interflow which is due to the flatness of the area. The stream flow has a large and perma-

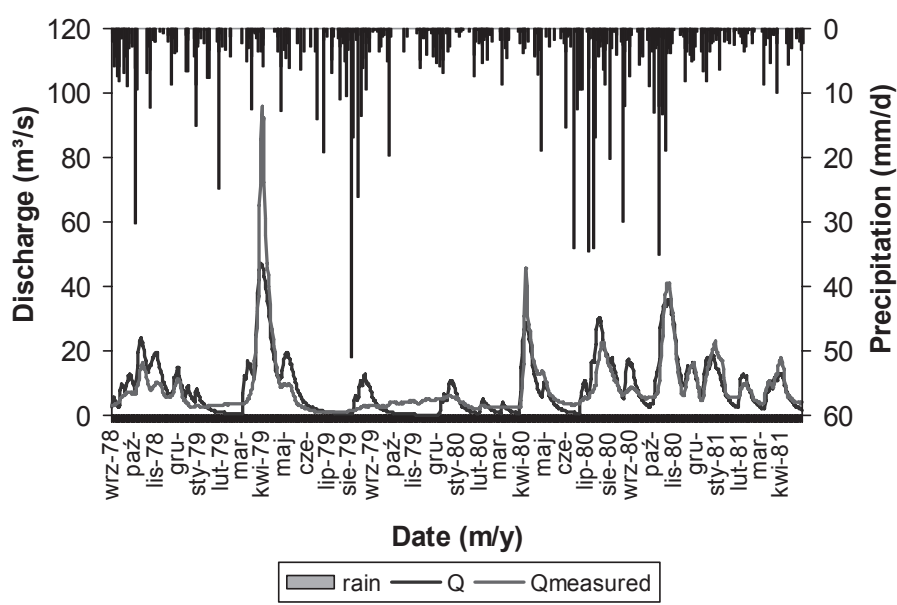

FIGURE 3. Calculated and observed discharge and observed rainfall in upper Biebrza River catchment for a wet period (01.11.1978 to 31.04.1981) 


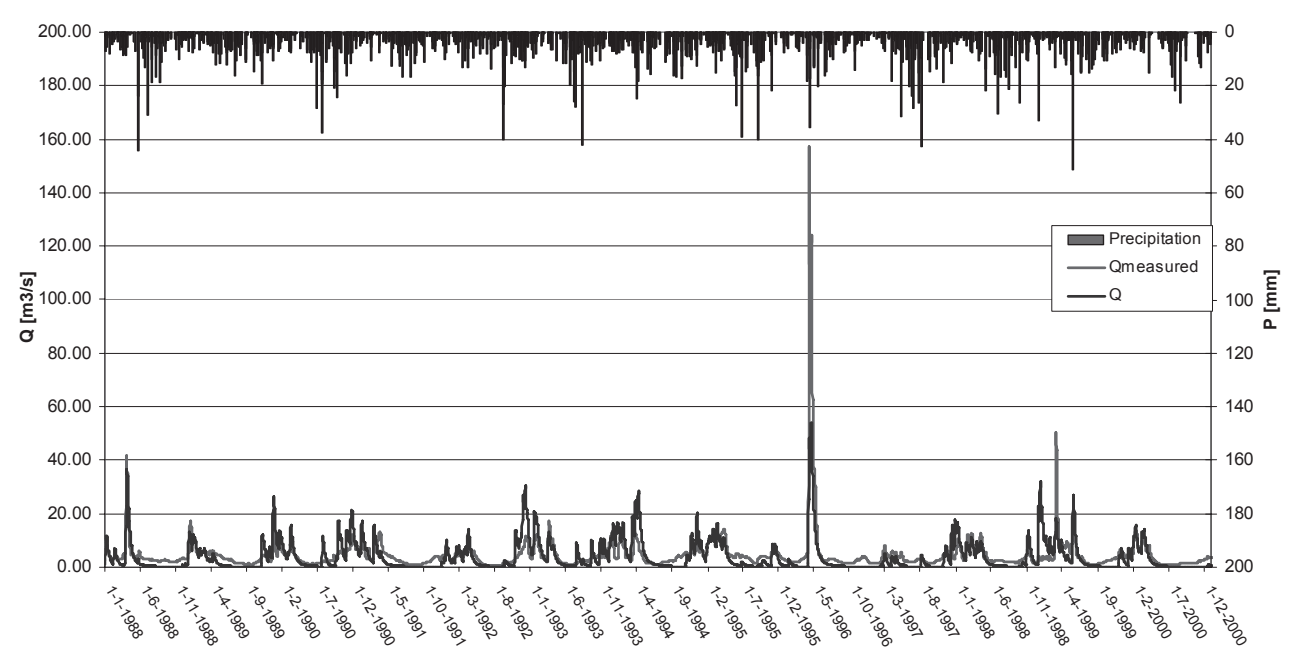

FIGURE 4. Calculated and observed discharge and observed rainfall in upper Biebrza River catchment for a dry period (01.05.1988-31.12.2000)

nent component of base flow. This shows that this wetland area is primarily fed by groundwater discharge.

The evaluation results for these criteria are listed in Table 2. One can notices that for the wet period the observed water balance $(\mathrm{C} 1)$ is reproduced with $1.5 \%$ overestimation, model determination coefficient (C2) is 0.717 , the NashSutcliffe efficiency (C3) is 0.732 for the time evolution of stream flows, and the modified Nash-Sutcliffe efficiency is 0.768 and -0.107 respectively for high (C4) and low flows (C5). The comparison of calculated and observed hydrograph shows very good and good agreement, especially for the flood events (with exception of the highest snowmelt flood.
The criteria obtained for a dry period has been not as good as for wet period, even if hydrograph comparison show not dramatic differences. It could be conclude that model need more improvement to be enough for simulation low flows.

These statistical evaluation results confirm the graphical evaluation results: model performance is satisfactory for water balance simulation and spring flood prediction, but not satisfactory for low flood simulation in the wetlands.

\section{CONCLUSIONS}

The rainfall-runoff model WetSpa was found as a proper tool, able to predict hydrologic processes and modeling

TABLE 2. Nash-Sutcliffe Efficiency C1-C5 for the calibration of WetSpa model for upper Biebrza River catchment at Sztabin gauge, for a wet and dry period

\begin{tabular}{|l|r|r|r|r|r|}
\hline Parameter & \multicolumn{1}{|c|}{ C1 } & C2 & C3 & C4 & C5 \\
\hline Wet period & 0.015 & 0.717 & 0.732 & -0.107 & 0.768 \\
\hline Dry period & -0.153 & 0.597 & 0.472 & -3.385 & 0.583 \\
\hline Optimum & 0 & 1 & 1 & 1 & 1 \\
\hline
\end{tabular}


both snowmelt and summer floods. The most of observed floods have been simulated with success, however very often they are overpredict or undersimulated. Several observed rainfall peaks have been not responsed by flood in reality but has been simulated by model, what could be easily explain by not sufficient rainfall data - one gauge in catchment. The analysis shows that a model came short in simulating low floods due to the simplified groundwater modelling component in WetSpa and not sufficient evapotranspration formula. Premilinary modelling shows that model and simulation results could be improved by future work which would be recommend as folows:

- Updating the base maps (especially soil map) in order to improve the WetSpa performance.

- Improving the method for calculating interception and actual evapotranspiration by including LAI and evaporation measured in different wetland vegetation types.

- Developing an improved method for snow-melt simulation, including spatial distribution of snow cover and its depth.

- Including discharge time series collected in sub-catchments (Nurka river, Sidra, Kamienna, Lebiedzianka, Jastrzebna) in model calibration.

- Development of Integrated model (catchment model for runoff and water balance, hydrodynamic model for river and floodplain, groundwater model).

- Including remote sensing techniques and satellite images as a spatial data source for description of seasonal vegetation changes and their influence on hydrological processes.

\section{Acknowledgement}

Financial support was received from the Polish Ministry of Science and Higher Education as part of the research project N30505232/1917 is greatly appreciated.

\section{REFERENCES}

BATELAAN O., KUNTOHADI T. 2002: Development and application of a groundwater model for the Upper Biebrza River Basin. Ann. Warsaw Agricult. University, Land Reclam. 33, 57-69.

CHORMAŃSKI J., VAN DE VOORDE T., DE ROECK T., BATELAAN O., CANTERS F. 2008: Improving Distributed Runoff Prediction in Urbanized Catchments with Remote Sensing based Estimates of Impervious Surface Cover, Sensors, 8, 910-932.

CHORMAŃSKI J., MICHAŁOWSKI R. 2011: Model hydrologiczny zlewni WetSpa zintegrowany z modułem obliczeniowym w środowisku ArcGIS. [Hydrological catchment model WetSpa integrated with a calculation module in ArcGIS environment] (English summary). Scientific Review Engineering and Environmental Sciences (in press).

KOSSOWSKA CEZAK U. 1984: Climate of the Biebrza ice-margin valley. Polish Ecol. Stud. 10 (3-4): 253-270.

LIU Y. 2004: A GIS - based Hydrologic Model for Flood Prediction and Watershed Management. Documentation and User Manual. Vrije Universiteit Brussel, Belgium, p. 315.

LIU Y.B., GEBREMESKEL S., DE SMEDT F., PFISTER L. 2002: Flood prediction with the WetSpa model on a catchment scale, [In:] Wu, B.S., Wang Z.Y., Wang G.Q., Huang G.H., Fang H.W., Huang J.C. (eds.), Flood Defence, Science Press, New York.

NASH, J., SUTCLIFFE J. 1970: River flow forecasting through conceptual models, part 1. A discussion of principles. $J$. $H y$ drol. 10, 282-290. 
OKRUSZKO H. 1990: Wetlands of the Biebrza Valley their value and future management. Warsaw, p. 107.

PORRETTA-BRANDYKL., CHORMAŃSKI J., IGNAR S., OKRUSZKO T., BRANDYK A., SZYMCZAK T., KRĘŻAŁEK K. 2010: Evaluation and verification of the WetSpa model based on selected rural catchments in Poland. J. Water Land Dev. 14, 115-133.

PORRETTA-BRANDYKL., CHORMAŃSKI J., BRANDYK A., OKRUSZKO T. 2011: Automatic calibration of the WetSpa distributed hydrological model for small lowland catchments. Geoplanet: Earth and Planetary Science (in press).

ROGUSKI W., SARNACKA S., DRUPKA S. 1988: Instrukcja wyznaczania potrzeb i niedoborów wodnych roślin uprawnych i użytków zielonych [Guidelines for predicting crop and pasture water needs]. Mat. Instrukt. 66, Falenty IMUZ.

DE SMEDT F., LIU Y.B., GEBREMESKEL S. 2000: Hydrologic modeling on a catchment scale using GIS and remote sensed land use information, [In:] Risk Analysis II, Ed. C.A. Brebbia, WTI press, Southampton, Boston, 295-304.

VAN LOON A.H., SCHOT P.P., GRIFFIOEN J., BIERKENS M.F.P., BATELAAN O., WASSEN M.J. 2009: Throughflow as a determining factor for habitat contiguity in a near-natural fen. J. Hydrol. 379, $30-40$.

WANG Z.M., BATELAAN O., DE SMEDT

F. 1996: A distributed model for water and energy transfer between soil, plants and atmosphere (WetSpa), Phys. Chem. Earth, 21(3), 189-193.

WASILEWSKI M., CHORMAŃSKI J. 2009: The Shuttle Radar Topography Mission Digital Elevation Model as an alternative data source for deriving hydrological characteristics in lowland catchment. Ann. Warsaw Univ. Life Sciences - SGGW Land Reclam., 41, 71-82.

WITTENBERG H., SIVAPALAN M. 1999: Watershed groundwater balance estimation using streamflow recession analysis and baseflow separation, J. Hydrol. 219, 20-33.

Streszczenie: Zastosownie hydrologicznego modelu o parametrach rozłożonych WetSpa $w$ zlewni o znaczacym udziale gleb organicznych, na przykładzie górnej Biebrzy. Artykuł dotyczy adaptacji modelu hydrologicznego o parametrach rozłożonych w zlewni o znaczącym udziale gleb organicznych. Zastosowany model WetSpa umożliwił dokonanie analizy wpływu topografii, rodzaju gleb i użytkowania terenu na charakterystyki odpływu w zlewni górnej Biebrzy. W pierwszym etapie określono parametry przestrzenne w postaci map, a następnie obliczano dobowy odpływ jako reakcję zlewni na opad. Do kalibracji wykorzystano procedurę półautomatyczną, stosując program PEST. Następnie przeprowadzono ocenę najważniejszych procesów, obliczając błędy modelowania matematycznego oraz porównując hydrogramy odpływu. Wielkości błędów pokazały wysoką skuteczność modelu w przypadku symulacji przepływów wysokich, lecz niesatysfakcjonujące wyniki w obliczaniu przepływów niskich. Ta wstępna analiza dała możliwość zadania pytań o granice i potrzeby w modelowaniu opad-odpływ na obszarach mokradłowych.

Stowa kluczowe: modelowanie o parametrach rozłożonych, opad-odpływ, kalibracje automatyczne, zlewnie nizinne.

\section{MS. received February 2011}

\section{Authors' addresses:}

Chormański Jarosław

Katedra Inżynierii Wodnej

Szkoła Główna Gospodarstwa Wiejskiego

ul. Nowoursynowska 159

02-776 Warszawa

Polska

e-mail: j.chormanski@levis.sggw.pl

Okke Batelaan

Dept. of Hydrology and Hydraulic Engineering

Vrije Universiteit Brussel

Pleinlaan 2, 1050 Brussels, Belgium

K.U.Leuven, Dept. of Earth and Environmental

Sciences

Celestijnenlaan 200e - bus 2410, 3001 Heverlee, Belgium 